\title{
Introduction: The Making of Sámi Religion in Contemporary Society
}

\author{
Trude Fonneland 1,*(D) and Tiina Äikäs ${ }^{2, *(D)}$ \\ 1 The Arctic University Museum of Norway and Academy of Arts (UMAK), \\ UiT-The Arctic University of Norway, P.O. Box 6050, N-9037 Langnes Tromsø, Norway \\ 2 Research Unit of History, Culture and Communications, University of Oulu, FI-90014 Oulu, Finland \\ * Correspondence: trude.fonneland@uit.no (T.F.); tiina.aikas@oulu.fi (T.Ä.)
}

Received: 30 June 2020; Accepted: 19 October 2020; Published: 23 October 2020

\begin{abstract}
This Special Issue of Religions approaches "Sámi religion" from a long-term perspective seeing both the past religious practices and contemporary religious expressions as aspects of the same phenomena. This does not refer, however, to a focus on continuity or to a static or uniform understanding of Sámi religion. Sámi religion is an ambiguous concept that has to be understood as a pluralistic phenomenon consisting of multiple applications and associations and widely differing interpretations, and that highlights the complexities of processes of religion-making. In a historical perspective and in many contemporary contexts (such as museum displays, media stories, as well as educational programs) the term Sámi religion is mostly used as a reference to Sámi pre-Christian religious practices, to Laestadianism, a Lutheran revival movement that spread among the Sámi during the 19th Century, and last but not least to shamanism. In this issue, we particularly aim to look into contemporary contexts where Sámi religion is expressed, consumed, and promoted. We ask what role it plays in identity politics and heritagization processes, and how different actors connect with distant local religious pasts-in other words, in which contexts is Sámi religion activated, by whom, and for what?
\end{abstract}

\section{Sámi Religion-Making}

What is often termed the Sámi religion or the pre-Christian Sámi religion refers to a set of beliefs and practices performed and communicated by people in an area contemporarily known as Sápmi, and described by missionaries, ethnographers, travellers, and various stakeholders over a long time span. As Pollan (2005, p. 416) argues, “What today is known as "Sámi religion", has for the Sámi themselves simply been their way of life"1. More than about a Sámi way of life, what scholars, missionaries, travellers, and stakeholders have been writing about is their own view of human history, and at the same time they have taken part in a social, economic, and political oppression. There are in other words no universals of Sámi religion. It is in creative encounters and in a process of translation that Sámi religion emerges as a category. The circulations of religious themes, which are clearly expressed in these processes, bring our attention to the flows of religion and religious change and renewal.

\section{Historical Background}

To be able to understand "Sámi religion" in contemporary society, some knowledge on the historical background is relevant. Sámi are the indigenous people whose homeland, today called

1 “Det som i dag kalles "samisk religion" har for samer selv ganske enkelt vært deres måte å leve på" (Pollan 2005, p. 416, our translation). 
Sápmi, stretches from Northern Norway to Northern Sweden, Northern Finland, and the Kola Peninsula in Russia. There are 75,000-100,000 Sámi depending on the method of counting, many of them living outside their homeland. Sámi culture is not or has not been uniform in this wide area as is demonstrated, for example, by the use of ten Sámi languages. The traditional livelihoods include hunting, fishing, gathering, reindeer herding, and crafts which are all also practiced today. There have also been differences in the religious practices in this wide area, but also some shared ideas.

The beginning of Sámi religion is hard to trace. Some researchers have seen a connection in the prehistoric rock art of Fennoscandia and the symbols in historical Sámi drums (e.g., Núñez 1995; Lahelma 2008; Joy 2018), a perspective which is also presented in contemporary museum exhibitions (Äikäs 2019). The long temporal and in some cases geographical distance makes the connection uncertain. The dating of the material traces incontrovertibly connected to Sámi religion, do nevertheless move back in time through new research, hence revealing longer roots of ritual practices than have been previously known. The Sámi offering places, sieidi (North Sámi, sieiddit in plural) have revealed bone material originating from the 6th century AD (Salmi et al. 2015, 2018). So-called hunting ground graves (Sw. fängstmarksgravar) and scree graves (Nw. urgraver) have been interpreted as even earlier signs of Sámi religion. Hunting ground graves have been in use in the South Sámi area from 200 BC to AD 1200/1300s and scree graves in Northern Norway between 300 BC and AD 1700, but their connection to the Sámi in the early stage of their use is uncertain (Schanche 2000; Fossum 2006; Piha n.d.).

Already in the Catholic times, Sámi had been in contact with the Christian Church. During the medieval period there were attempts to Christianize the Sámi, mainly through the efforts of the Orthodox Church in Russia (Hansen and Olsen 2014). Furthermore, in the Protestant time there were remains of Catholic beliefs, e.g., Johannes Schefferus describes how many Sámi refrained from eating meat on Fridays (Scheffer 1673). The process of Christianization can best be described as a protracted process, and not as a streamlined operation starting in the south and ending in the north. The Sámi people's conversion was in other words multifaceted and occurred at different times in the various communities throughout Sápmi (see Rasmussen 2016, pp. 77-95).

\section{Effects of Colonialism}

Nation-state colonization has been a destructive presence throughout Sámi history. From the 14th century onward, the contacts between the Sámi and the Swedish- and Finnish-speaking agrarian populations increased as the agrarian population slowly colonized northern areas. From the 17th century onwards the Sámi experienced an increasing pressure of colonial contacts when the Nordic states started to take control of the land in the north by supporting settlement and trade and introducing their own administrative systems. Later, in 1852, the establishment of present state borders led to problems in the traditional livelihoods when yearly migrations in relation to reindeer herding were prevented. In the 19th century, Nordic states launched assimilation policies where, for example, Sámi children were not allowed to speak Sámi languages in schools (Wallerström 2000; Lantto 2010; Hansen and Olsen 2014; Lehtola 2014; Nyyssönen 2014; Äikäs and Salmi 2015).

The 17th century saw the expansion of the Lutheran mission which intensified the building of churches and work of missionaries in Sápmi. Among the Sámi there were those who actively or passively opposed the new religion, but also those who themselves practised missionary work (Rydving 1993). The arrival of Christianity did not nevertheless mean the end of the old Sámi religion but old practices lived side by side with the new ones. For example, the sieidi stones still received offerings as well as did some churches (Kylli 2005, 2012; Äikäs 2015), and the use of sieidi stones continues even in contemporary times (Äikäs and Spangen 2016; Spangen and Äikäs in this volume). The conversation process has, nevertheless, been seen as a colonizing one. It included the destroying of Sámi sacred places and of ritual drums, and Sámi religion as a comprehensive religious system was disrupted, hence leaving a need for later reconciliation processes by the church (West in this volume). 
Even today this conflict is evident, for example in the opposition raised by using traditional Sámi yoik singing in churches (https://yle.fi/uutiset/3-10849229).

The interplay between Christianity and Sámi religion leads to a challenge with the term "pre-Christian". Sámi religion did not only precede Christianity but was practiced simultaneously with it. Hence other terms such as traditional, indigenous, or ethnic religion have also been used (e.g., Spangen 2013; Äikäs 2015; Lund 2015; cf. Kaikkonen in this volume). On the other hand, Sámi religion can also refer to Orthodoxy practices especially by the Skolt Sámi (Vuola 2019) or to Lutheranism and the Laestadian movement. Lars Levi Laestadius (1800-1861) started working in the parish of Karesuvanto in 1826. His work is another example of the intertwining of old religion and the new one. He formulated and adapted his own interpretations of Christianity to the Sámi environment. In his sermons, he for instance included Sámi mythology by making references to Stállu (a figure who appears in various roles in Sámi folklore) and to the mother goddess (áhkká-Virgin Mary) (Hallencreutz 1987).

\section{From Noaidi to Shaman}

In recent years, attitudes towards "Sámi religion" have changed both within religious, cultural, political, and educational contexts. Contemporarily, the term shaman has become an umbrella term for the Sámi noaidi (a north Sámi term for the Sámi indigenous religious specialist), as is the case with religious specialists among people referred to as "indigenous", more or less regardless of the content of their expertise and practices. However, the noaidi has not always been perceived as a shaman. As David Chidester points out, the shaman is a religious specialist that initially was identified in Siberia, colonized by Russia, and later transferred to a global arena (Chidester 2018). The "shaman" in other words is an example of the complexities often involved in translation processes over time and across space (see Johnson and Kraft 2017). The term is widely regarded as having entered Russian from the Tungus samán, transferring to German as schamane, and then into other European languages in the seventeenth century. It was added to academic vocabularies by anthropologists and historians of religions and further related to indigenous people elsewhere (see Wilson 2014, p. 117) ${ }^{2}$. In the 1960s, the term spread to the pagan milieu where the shaman is not only recognised as an indigenous religious specialist, but as a potential enshrined in all humans. When it comes to these types of translation processes that the term shaman has been subjected to, it is important to have in mind what James Clifford highlights in terms of the concept of translation: "Translation is not transmission [ ... ] Cultural translation is always uneven, always betrayed. But this very interference and lack of smoothness is a source of new meanings, of historical traction" (Clifford 2013, pp. 48-49).

In the 1960s shamanism emerged as a global category and phenomenon with shamans in many parts of the world sharing common practices, rituals, and a nature-oriented worldview and lifestyle. The highlighting of shamanism as a universal phenomenon is inspired by the English translation of Romanian historian of religion Mircea Eliade's Shamanism: Archaic Techniques of Ecstasy (Eliade 1964). However, within this global fellowship, diversity is still the most prominent feature and shamanism is not inevitably describable as a uniform tendency on a global scale. Diversity is displayed in terms of the various traditions that the practitioners choose to follow and revive, in terms of practices, politics, values, and where it is all taking place. What this means is that studies of the dynamics of shamanic entrepreneurships in one particular place are not necessarily directly transferable to other local contexts. Although the United States can be described as the cradle of modern shamanism, the spread of shamanic

2 Konsta Kaikkonen in his Ph.D. Contextualising Descriptions of Noaidevuohta: Saami Ritual Specialists in Texts Written until 1871 points out that the discourse of "Sámi shamanism" entered the academic world through the paradigm of comparative mythology as it was adopted by the Finnish ethnographer and linguist Matthias Alexander Castrén in the 1840s, and that the Norwegian linguist Jens A. Friis, building on Castrén's theories and ideas, in 1871 introduced the discourse to the up and coming field of "lappology" (Kaikkonen 2020, manuscript edition). 
religious practices and ideas to other habitats is not a uniform process, but involves adaptations to local cultural and political climates.

Indian-style shamanism reached the Nordic region during the 1970s, along with New Age and occult impulses. Prior to the late 1990s, shamanism in the Nordic countries differed little from shamanisms found elsewhere in the Western world. In previous studies, Fonneland has traced the history of the process of giving shamanism an indigenous Sámi flavour to the Sámi author and journalist Ailo Gaup (1944-2014) who is considered the first Sámi shaman in Norway (see Fonneland 2010, 2017). Gaup's story reveals both a strong influence from Harner's core shamanism and a strong desire to bring forth Sámi religious traditions as a basis for religious practice in contemporary society (see Gaup 2005).

The Western world's fascination with shamanism is by no means a recent phenomenon. The historical background has been meticulously documented among others by Ronald Hutton (2001), Von Stuckrad (2003), and Andrei Znamenski (2007). Contemporarily, several researchers claim that shamanism is one of the fastest growing religions in the Western world (Wallis 2003, p. 140; Partridge 2004, p. 47). In the Nordic countries, this growth is reflected in both secular and religious arenas. Various shamanic festivals with different content and scope have recently seen the light of day (see Fonneland 2015a). New shamanic denominations offering shamanic ceremonies are constructed (see Fonneland 2015b), and a growing corpus of shamans are offering their services and products to the public (see Joy, this volume). Furthermore, shamanism and articulations of Sámi religion are expressed in secular arenas like in the tourism industry, in media, in films, in products for sale and consumption as well as in the education system (see Andreassen and Olsen, Kalvig, and Fonneland this volume). Another arena where shamanism has been recently activated is in various forms of political activism, often with a focus on concerns for the environment and on saving the climate (see Kraft and Vassvik, this volume). The diverse and complex contemporary expressions of Sámi religion and shamanism can be described as processes of religion-making. Religion-making, according to a model developed by Markus Dressler and Arvind Mandair is expressed in diverse arenas and is a process that emerges from various positions of power that also comprise secular institutions (Dressler and Mandair 2011).

\section{Appropriation and Agency}

In the contexts mentioned above, indigeneity and "indigenous religion" is approached as a cultural capital (Bourdieu 1973). By a range of diverse actors and for a variety of reasons, indigenous spirituality is seen as something that is worth pursuing, owning, and consuming. This has led to controversies and to questions about appropriation. Colonialism is not just about territorial claims, economic strategies, and racial ideologies; it also involves the appropriation of material culture (Naum and Nordin 2013; Äikäs and Salmi 2019). The colonial background mirrors the problems in contemporary society, where Sámi cultural symbols are used for commercial and entertainment purposes without proper knowledge or appreciation of Sámi culture (Mikkonen 2016; Näkkäläjärvi 2016; Seitsonen 2018, p. 149). For example, the use of a mock version of the Sámi costume, gákti, by non-Sámi has raised strong objections. Furthermore, religious symbols such as figures from noaidi-drums are widely used in souvenirs and hotel interiors (Mathisen in this volume).

As noted by Fonneland and Kraft (2013), there is no shortage of convincing examples to support charges of cultural theft and demeaning practices. However, this is not the whole story. Current conditions are, at least in the case of the Sámi, far more complex than those depicted in the established scenario of indigenous victims of appropriation. Such a scenario fails to account for the presence of indigenous people on these same scenes, including Sámi shamans and the voices of indigenous spirituality. The agency of all parties needs to be acknowledged in these types of meetings, which hence does not yield to simple theories of objectivation and appropriation.

In this special issue, we take account of emic categories and connections, focusing on which notions of "Sámi religion" are used today by religious entrepreneurs and others who share and promote these types of spiritual beliefs, and how Sámi religion is taking shape on a plenitude of arenas 
in contemporary society. The volume brings together researchers from a wide range of disciplines including religious studies, theology, archaeology, art sciences, tourism studies, cultural studies, and educational sciences and offers manifold perspectives on the making of Sámi religion and of the ways Sámi religion is activated and communicated in contemporary society.

Author Contributions: T.F. wrote the first draft of the article and revised the final version. T.Ä.'s main responsibility was on the sections on historical background and colonialism. All authors have read and agree to the published version of the manuscript.

Funding: This research received no external funding.

Conflicts of Interest: The authors declare no conflict of interest.

\section{References}

Äikäs, Tiina. 2015. From Boulders to Fells: Sacred Places in the Sámi Ritual Landscape. Translated by S. Silvonen. Monographs of the Archaeological Society of Finland 5. Available online: http://www.sarks.fi/masf/masf_5/ masf_5.html (accessed on 20 October 2020).

Äikäs, Tiina. 2019. Religion of the past or living heritage? Dissemination of knowledge on Sámi religion in museums in Northern Finland. Nordic Museology 19: 152-68.

Äikäs, Tiina, and Anna-Kaisa Salmi. 2015. North/south encounters at Sámi sacred sites in Northern Finland. Historical Archaeology 3: 90-109. [CrossRef]

Äikäs, Tiina, and Anna-Kaisa Salmi. 2019. Introduction. In search of Indigenous voices in the historical archaeology of colonial encounters. In The Sound of Silence. Indigenous Perspectives on the Historical Archaeology of Colonialism. Edited by Tiina Äikäs and Anna-Kaisa Salmi. New York: Berghahn Books, pp. 1-14.

Äikäs, Tiina, and Marte Spangen. 2016. New users and changing traditions: (Re)defining Sami offering sites. European Journal of Archaeology 49: 95-121. [CrossRef]

Bourdieu, Pierre. 1973. Cultural reproduction and social reproduction. In Knowledge, Education and Social Change. Edited by Richard Brown. London: Tavistock, pp. 71-112.

Chidester, David. 2018. Religion: Material Dynamics. Oakland: University of California Press.

Clifford, James. 2013. Returns. Becoming Indigenous in the Twenty-First Century. London: Harvard University Press. Dressler, Markus, and Arvind-Pal S. Mandair. 2011. Secularism and Religion-Making. Oxford: Oxford University Press. Eliade, Mircea. 1964. Shamanism. Archaic Techniques of Ecstasy. Princeton: Princeton University Press.

Fonneland, Trude. 2010. Samisk Nysjamanisme: I Dialog Med for (tid) Og Stad. Ph.D. thesis, The University of Bergen, Bergen, Norway.

Fonneland, Trude. 2015a. The festival Isogaisa: Neoshamanism in new arenas. In Nordic NeoShamanisms. Edited by Trude Fonneland, Siv Ellen Kraft and James Lewis. New York: Palgrave MacMillan, pp. 215-34.

Fonneland, Trude. 2015b. "The Rise of Neoshamanism in Norway: Local Structures-Global Currents". In Nordic NeoShamanisms. Edited by Trude Fonneland, Siv Ellen Kraft and James Lewis. New York: Palgrave MacMillan, pp. 33-54.

Fonneland, Trude. 2017. Contemporary Shamanisms in Norway. Religion, Entrepreneurships and Politics. Oxford: Oxford University Press.

Fonneland, Trude, and Siv Ellen Kraft. 2013. Sami Shamanism \& Indigenous Spirituality. In New Age Spirituality. Rethinking Religion. Edited by I. Gilhus and S. Sutcliffe. London: Equinox Publishers, pp. 132-45.

Fossum, Birgitta. 2006. Förfädernas land. En arkeologisk studie av rituella lämningar i Sápmi, 300 f.Kr.-1600 e.Kr. Studia Archaeologica Universitatis Umensis 22. Umeå: Institutionen för arkeologi och samiska studier, Umeå universitet.

Gaup, Ailo. 2005. The Shamanic Zone. Oslo: Three Bear Company.

Hallencreutz, Carl. 1987. Lars Levi Laestadius' attitude to Saami religion. Scripta Instituti. Donneriani Aboensis 12: 170-84. [CrossRef]

Hansen, Lars Ivar, and Bjørnar Olsen. 2014. Hunters in Transition: An Outline of Early Sámi History. Leiden: Brill.

Hutton, Ronald. 2001. Shamans: Siberian Spirituality and the Western Imagination. London and New York: Hambledon and London. 
Johnson, Greg, and Siv Ellen Kraft. 2017. Introduction. In The Brill Handbook of Indigenous Religion(s). Pathways_Being, Becoming, Back. Edited by Greg Johnson and Siv Ellen Kraft. Leiden and Boston: Brill, pp. 1-24.

Joy, Francis. 2018. Sámi Shamanism, Cosmology and Art: As Systems of Embedded Knowledge. Rovaniemi: Lapin yliopisto.

Kaikkonen, Konsta Ilari. 2020. Contextualising Descriptions of Noaidevuohta: Saami Ritual Specialists in Texts Written until 1871. Ph.D. thesis, manuscript edition. the University of Bergen, Bergen, Norway.

Kylli, Ritva. 2005. Kirkon ja saamelaisten kohtaaminen Utsjoella ja Inarissa 1742-1886. Rovaniemi: Pohjois-Suomen historiallinen yhdistys.

Kylli, Ritva. 2012. Saamelaisten kaksi kääntymystä: Uskonnon muuttuminen Utsjoen ja Enontekiön lapinmailla 1602-1905. Helsinki: Suomalaisen Kirjallisuuden Seura.

Lahelma, Antti. 2008. A Touch of Red. Archaeological and Ethnographic Approaches to Interpreting Finnish Rock Painting. Iskos 15. Helsinki: Finnish Antiquarian Society.

Lantto, Patrik. 2010. Borders, citizenship and change: The case of the Sami people, 1751-2008. Citizenship Studies 14: 543-56. [CrossRef]

Lehtola, Veli-Pekka. 2014. Katekeettakouluista kansakouluihin: Saamelaisten kouluhistoriaa 1900-luvun alkupuoliskolla. In Saamelaisten kansanopetuksen ja koulunkäynnin historia Suomessa. Edited by Pigga Keskitalo, Veli-Pekka Lehtola and Merja Paksuniemi. Turku: Siirtolaisuusinstituutti, pp. 44-62.

Lund, Julie. 2015. Living places or animated objects? Sámi sacrificial places with metal objects and their South Scandinavian parallels. Acta Borealia: A Nordic Journal of Circumpolar Societies 32: 20-39. [CrossRef]

Mikkonen, Nadja. 2016. Kyse on oikeudesta maahan, kieleen ja kulttuuriin. YLE uutiset. September 19. Available online: https://yle.fi/uutiset/3-9135075 (accessed on 24 April 2020).

Näkkäläjärvi, Pirita. 2016. Näkökulma: Närkästyneet saamelaiset otsikoiss. YLE uutiset. May 16. Available online: https://yle.fi/uutiset/osasto/sapmi/nakokulma_narkastyneet_saamelaiset_otsikoissa/8877876 (accessed on 24 April 2020).

Naum, Magdalena, and Jonas M. Nordin. 2013. Introduction: Situating Scandinavian colonialism. In Scandinavian Colonialism and the Rise of Modernity: Small Time Agents in a Global Arena. Edited by Magdalena Naum and Jonas M. Nordin. New York: Springer, pp. 3-16.

Núñez, Milton. 1995. Reflections on Finnish rock art and ethnohistorical data. Fennoscandia Archaeologica 12: 123-35.

Nyyssönen, Jukka. 2014. Saamelaisten kouluolot 1900-luvulla. In Saamelaisten kansanopetuksen ja koulunkäynnin historia Suomessa. Edited by Pigga Keskitalo, Veli-Pekka Lehtola and Merja Paksuniemi. Turku: Siirtolaisuusinstituutti, pp. 63-86.

Partridge, Cristopher. 2004. The Re-Enchantment of the West. London: T\&T Clark, vol. 1.

Piha, Minerva. n.d. Archaeological and lexical perspectives on the indigenous South Saami religion. In Entangled Beliefs and Rituals: Religion in Finland and Sápmi from Stone Age to Contemporary Times. Edited by Tiina Äikäs and Sanna Lipkin. Monographs of the Archaeological Society of Finland, in press. Available online: http://www.sarks.fi/julkaisut_masf.html (accessed on 20 October 2020).

Pollan, Brita. 2005. Samisk religion i Norge. In Norges religionshistorie. Edited by Arne Bugge Amundsen. Oslo: Universitetsforlaget.

Rasmussen, Siv. 2016. Samisk integrering i norsk og svensk kirke i tidlig nytid: En komparasjon mellom Finnmark og Torne Lappmark. Ph.D. dissertation, University of Tromsø, Tromsø, Norway.

Rydving, Håkan. 1993. The End of Drum-Time: Religious Change among the Lule Saami, 1670s-1740s. Acta Universitatis Upsaliensis. Historia Religionum 12. Uppsala: Uppsala University.

Salmi, Anna-Kaisa, Tiina Äikäs, Markus Fjellström, and Marte Spangen. 2015. Animal offerings at the Sámi offering site of Unna Saiva: Changing religious practices and human-animal relationships. Journal of Anthropological Archaeology 40: 10-22. [CrossRef]

Salmi, Anna-Kaisa, Tiina Äikäs, Marte Spangen, Markus Fjellström, and Inga-Maria Mulk. 2018. Tradition and transformation in Sámi animal-offering practices. Antiquity 92: 472-89. [CrossRef]

Schanche, Audhild. 2000. Graver i ur og berg. Samisk gravskikk og religion fra forhistorisk til nyere tid. Karasjok: Davvi Girji OS. 
Scheffer, Johannes. 1673. Joannis Schefferi Argentoratensis Lapponia: Id est, regionis Lapponum et gentis nova et verissima descriptio. In qua multa de origine, superstitione, sacris magicis, victu, cultu, negotiis Lapponum, item Animalium, metallorumque indole, quæ in terris eorum proveniunt, hactenus incognita Produntur, E eiconibus adjectis cum cura illustrantur. Francofurti: Ex Officina Christiani Wolffii.

Seitsonen, Oula. 2018. Digging Hitler's Arctic War. Archaeologies and Heritage of the Second World War German Military Presence in Finnish Lapland. Doctoral dissertation, University of Helsinki, Helsinki, Finland.

Spangen, Marte. 2013. 'It could be one thing or another': On the construction of an archaeological category. Fennoscandia Archaeologica 30: 67-80.

Von Stuckrad, Kocku. 2003. Discursive Study of Religion: From States of the Mind to Communication and Action. Method and Theory in the Study of Religion 15: 255-271. [CrossRef]

Vuola, Elina Inkeri Tellervo. 2019. The Mother of God in Finnish Orthodox Women's piety: Converted and Skolt Sámi voices. In The Oxford Handbook of Mary. Edited by Chris Maunder. Oxford: Oxford University Press, pp. 195-212.

Wallerström, Thomas. 2000. The Saami between East and West in the Middle Ages: An Archaeological Contribution to the History of Reindeer Breeding. Acta Borealia 17: 3-39. [CrossRef]

Wallis, Roy J. 2003. Shamans/Neo-Shamans: Ecstasy, Alternative Archaeologies and Contemporary Pagans. London: Routledge.

Wilson, David Gordon. 2014. Redefining Shamanisms. Spiritualist Mediums and Other Traditional Shamans as Apprenticeship Outcomes. London: Bloomsbury Academic.

Znamenski, Andrei A. 2007. The Beauty of the Primitive. Shamanism and the Western Imagination. Oxford: Oxford University Press.

Publisher's Note: MDPI stays neutral with regard to jurisdictional claims in published maps and institutional affiliations.

(C) 2020 by the authors. Licensee MDPI, Basel, Switzerland. This article is an open access article distributed under the terms and conditions of the Creative Commons Attribution (CC BY) license (http://creativecommons.org/licenses/by/4.0/). 